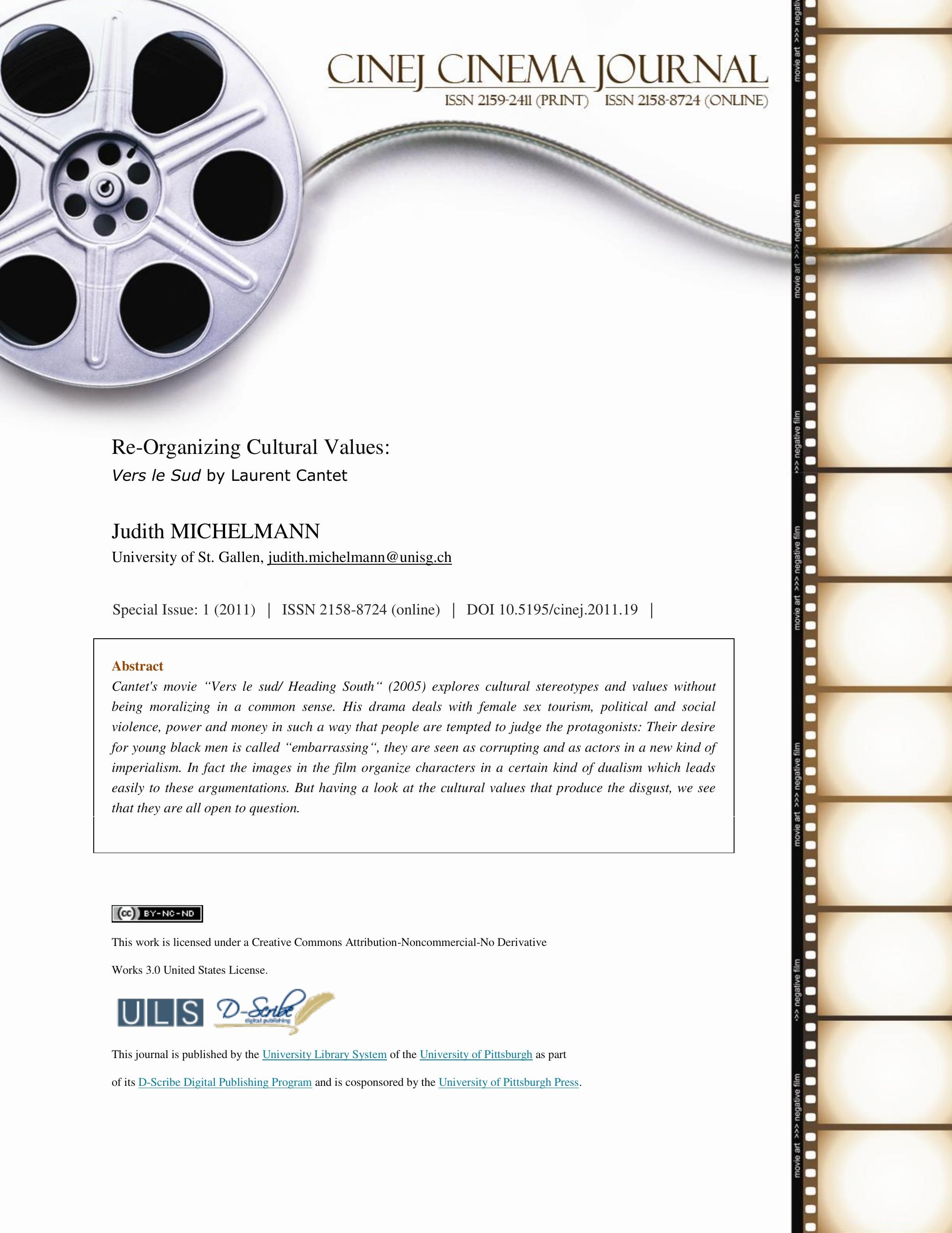




\section{Re-Organizing Cultural Values: Vers le Sud by Laurent Cantet}

\section{Allusions to Paradise and Hell}

The most beautiful and most frequently used visions of escaping workaday life in a Western society include a paradise island with palm trees, turquoise green water, white sand and - of course - passionate scenes near the sea. Laurent Cantet's 2005 movie Vers le sud picks up this theme and portrays three women travelling to Haiti. But it wouldn't be a Cantet movie, if the story didn't turn out a bit more complicated. The women travelling to the Caribbean are women of a certain age, lonely souls from the United States of America and from Canada, and they actually do not have funny flirts with the locals. They are donating presents for having company and for sexual services. One could argue that the film deals with sex tourism and prostitution, but if this is true, this is only part of the picture Cantet designed for his audience. In a broader sense he shows people threatened by political and social violence, implicated in power structures and alienated in a capitalistic system where money can do much more harm than a weapon.

A subtitle at the beginning of the movie sketches out time and place: "Haiti, late Seventies". Cantet has chosen the era of the Duvalier dictatorship as a frame of reference for his filmic exploration. In the history of the Caribbean island this era is widely known as a reign of terror, under the leadership of François "Doc" Duvalier (1957 to 1971) and, after, 1971 under his son Jean-Claude "Baby Doc" Duvalier. Opponents who spoke out against the Duvalier family were kidnapped at night or attacked in broad daylight; armed forces stoned or burned people alive and hung their corpses in trees. Removing a body and burying it meant risking one's own life. Cantet's film opens with a scene which refers to this humanitarian tragedy. At the airport a creole woman touches the hand of Albert, the resort manager, who has come to wait for Brenda, one of the female clients from the United States. The gray-haired woman is begging Albert desperately to take her daughter with him, since 'they' took her husband away and she isn't able to pay for her apartment and the education of her daughter anymore: "Regardez-la. Elle est avec moi là-bas en jaune. Cette fille a eu le malheur d' être belle et pauvre dans ce pays. Ils ne lui laisseront aucune chance. Je l'emmène partout avec moi pour veiller sur elle. Mais je sais qu'ils n'hésisteront pas à me tuer pour la prendre. Cela ne me fait rien de mourir mais je ne veux pas la leur laisser...pas elle. Je vous en prie, Monsieur, prenez-la avec vous." Albert refuses. The audience doesn't get to know why, whether it is against his morals to take a fifteen-year-old girl with him, or if he fears the responsibility or the omnipresence of the Milice de Volontaires de la Sécurité Nationale (MVSN). This paramilitary group served as one of the power sources of the Duvalier family. The Haitians called it the "Tonton Macoutes", after the mythological Tonton Macoute (Uncle Gunnysack) bogeyman who kidnaps and punishes disobedient children by stowing them in a gunnysack (Macoute) and carrying them off, never to be seen again (Rotberg 1997, 150). In fact, the estimated number of Haitians murdered or executed by the Tonton Macoutes ranges from 30,000 to 60,000 (Weinstein/ Segal 42). Anyone who challenged the MVSN risked assassination. To fully understand the fundamental role the militiamen of the Tonton Macoutes played in Haitian society, it is important to know that some of the most important members were voodoo leaders in their communities, and this religious affiliation provided them with authority in the eyes of the public: "One of the most intriguing aspects of Haitian governmental politics during the Duvalier era was its pervasive ramifications and far-reaching influence on the Voodoo belief system and its co-optation of local Voodoo leaders“ (Manigat in Laguerre 510). In everyday life, the Macoutes appeared to extort money: People were asked to pay special "contributions" (Rotberg 1988, 106) for public works. This money was used as a source of profit for corrupt officials, for personal enrichment among the leadership and even for Duvalier himself. 
Within Cantet's movie the Macoutes appear only once in a scene where the male protagonist Legba is playing football with his pals. In the background of the scene two men appear taking beer from a child who sells cool drinks on the street. The child obviously doesn't recognize the men as Macoutes and complains about not being paid. Immediately, the two men are angry, kicking the child's ice-box, smashing down to the ground nearly all the bottles. People look away in fear. Only another minor tries to help the young vendor but is held off by Legba not to cause any problems. These two scenes and, of course, the murdering of Legba and his girl-friend at the end of the movie provide a narrative staging of the political and social problems of Haiti: the universal fear of random violence among the population and as a consequence the decline of solidarity and the widespread feeling of loneliness. In the car-scene Legba's girl-friend complains about feeling alone. Speaking in her mother-tongue creole - she confesses that she needs a friend, someone to rely on, and to talk to without paying attention to every single word. She had had many lovers, but never a friend. And this is true in a double sense. The young woman thought of her driver Frank as a friend, but it turned out that Frank killed Legba and the young lady and thereby fulfilled the cryptic final statement of the creole woman at the airport: "Prenez garde Monsieur, les bons masques sont mélangés avec les mauvais, mais tous portent un masque.“

Aside from insecurity as an everyday life experience, poverty is another striking problem Cantet displays in Vers le sud. The street scenes that follow Brenda's arriving at Port au Prince show destruction, shabbiness, dirt, a mob of people. Even in 2006, four years before the earthquake, television reported that " $80 \%$ of the population lives below the poverty line, $65 \%$ are unemployed [...] and child slavery and forced labor are socially acceptable means of ensuring that working women and men - that is, those with jobs in the formal sector of the economy have a steady supply of domestic workers" (TV5 Monde in Lionnet 231). Poverty is one of the main reasons why male and female inhabitants of the island consider every means to escape hunger and death. When Legba asks his girl-friend in the movie why she came to the house of Colonel Beauvais and became his mistress, she answers that he gave her presents and that she feared his power. Cantet constructed this as a parallel to the 'biography' of Legba. When the Americans Brenda and her husband found him at the supposed age of fifteen, he hadn't eaten anything for days. So he was invited by the couple to share their meal, which became common in the following time. Brenda describes it as if they nearly adopted him as a child. In other words, they established a structure of dependency. In a monologue which is arranged in a documentary style, Brenda confesses later a sexual assault which is highly involved with this structure of dependency: One day when she and Legba were lying at the beach, she began to caress Legba's body and even his "cock". Encouraged by the fact that it immediately started getting hard, she "threw herself on him" and had sex with him.

Neither the seduction or abuse of Legba nor that of his girl-friend are visualized in the movie, they are just reported or evoked as being a fact, and it is remarkable that these reports don't mention any sign of resistance; even the girl-friend who tells her own story doesn't communicate rape, but talks of presents and implicit violence. Staging this, Cantet shows how desperate the situation of young people is: it involves their physical dependency, but also their mental status, that ranges from immaturity to pragmatism or fatalism.

In Vers le sud we are not confronted with conversations about prostitution; the word isn't even used. Cantet shows happy scenery within the resort "Petite Anse", where female tourists and young male locals are having fun together, sprawling on the beach, eating together, smoking marihuana, dancing, caressing each other. It seems to be such a peaceful "workplace" that even children want to take part in it. Cantet used the character of young Eddy to outline how being an object of desire to female tourists becomes a desirable profession. Sitting with the other men next to Brenda, Ellen and Sue, Eddy observes how his older friends lay their arms around the women, how they carry their bags, listen to their stories and get generous rewards for that: food out of the restaurant, golden chains, new clothes, dollars and whatever else they wish. Of course young Eddy tries to get 
himself into business, but is always sent away, being told: "You are too young". But the spectator knows: A reallife Eddy won't be too young one day, and moreover there are women like Brenda, who apparently prefer very young men. Considering this, social violence takes place everywhere, even in the conversations of the women. When Brenda surprisingly asks herself if she committed adultery dancing cheek to cheek with Eddy (seemingly unaware of the distortion of not mentioning Legba), Sue tells her not to make up her mind: "Here everything is different."

Considering this, the Haitian tourist resort appears "like a devil's version of paradise" (LaSalle) or like an "enfer" (hell), as Ellen calls it after Legba had been attacked. Cantet shows not only the natural beauty but also the political and social violence affecting the experiences of the protagonists. The development of the action constantly walks the line between adultery and love story, abuse and perfect match, and Cantet leaves it to the audience to judge.

\section{Visual Dichotomy and Narrated Equation}

Definitely, the movie images in Vers le sud can be characterized by a certain dichotomy. Due to the fact that Cantet shows his female North American protagonists interacting with young Haitian consorts, he visualizes necessarily a number of differences: men and women, black and white, poor and rich, young and old, barely naked and well-dressed. Doing this, he stages a cultural encounter which had rarely been presented in movies before: white women of a certain age who surround themselves with young black (political correct??? coloured???) lovers. As a social phenomenon this kind of tourist relation existed in a broader range since the Seventies (Frohlick 54). But both in arts and social sciences it didn't appear as a theme for a long time. This could be explained by several reasons. One of the most important is that it has been nearly impossible to collect valuable statistical data, because women were generally not used to talking about sexual affairs which wouldn't be accepted in their own social environment and, of course, working on that topic led to a certain self-stigmatization, too. To Cantet the previous neglect of the theme turned out as an advantage: His pictures appear to be fresh, different and potentially provocative. Moreover, the images challenge cultural rules, old ones and new ones, which are related to socially appreciated and non-appreciated interpersonal relationships.

For example, to nationalist or patriotic Haitians the relation between black and white is still a red rag. In the movie, Albert, the resort manager, is the one who verbalizes the cultural unease: His grand-father had never shaken the hand of a white man and he would have died of shame if he had known that his grandson served whites. Colonialism had left its marks in Haiti; more than one time in history the descendants of the African negro slaves had to fight for their liberty and political independence from 'white' oppressor nations. In 1804, when Dessalines declared independence from France and his military forces massacred most of the remaining French colonists, he proclaimed: "we have rendered to these true cannibals, war for war, crime for crime, outrage for outrage" (Dessalines 197). At the beginning of the 20th century the United States occupied Haiti and again it was a very troublesome process to repel their power. In this context, contact between Haitian people and North Americans or Europeans is always framed by historical experiences. Albert's concerns have their reasons: Just at the beginning of the movie, when Brenda arrives at the hotel beach followed by a young black waitress, the spectator easily recognizes colonial scenes of mistress and slave. This overlapping of movie picture and mental picture occurs again in the scene in which Ellen reclines upon her sunlounger and Legba and Eddy sit in front of her in the white sand. As the historical pictures are still present in cultural consciousness, they get mixed up with the movie pictures during the experience of the work. This is a chance, of course, in the sense of an active political consciousness, but it is - at the same time - a danger, because the spectator isn't able anymore to see the 
protagonists as individuals in their time. He or she immediately categorizes them in a historical matrix and stylizes the figures consequently into offenders and victims according to historical experience.

Besides, relationships between old and young, especially when it concerns old women and very young men, are often considered to be inappropriate. All the more so, when adultery might be a theme. The movie scene that shows Brenda dancing cheek-to-cheek with young Eddy, while the other couples relax on the beach, plays again with previous knowledge. In her monologue, Brenda describes her sexual assault upon Legba, which took place three years ago according to the storyline. When she dances in one of the following scenes with another under-aged boy, because she hasn't found another companion, the spectator becomes a witness, due to his or her cognisance. The scene is - separated from the others - just an innocent episode, in which two people who are cast aside by their group find each other and have fun together. With the knowledge from Brenda's monologue the scene immediately loses its innocence. Brenda becomes the habitual criminal, the paedophile, the woman who transgresses sacrosanct boundaries: It's not only that she, as a woman of a certain age, loves younger men, which would be scandalous also - no, in her case she touches a child, again. When Legba, who observes the dancers, gets angry and sends Eddy away, it's uncertain if he is motivated by jealousy or by worries about Eddy. From an external point of view, the spectator isn't able to judge.

Furthermore, the clash between poor and rich provides highly conflictual film material. This kind of cultural encounter is staged when Brenda visits the local market in Port au Prince together with Legba. Apparently, she had dressed up Legba that day according to her personal taste. He wears a blue-on-blue business outfit and follows Brenda on her way through the streets, carrying her bags. The couple is surrounded by traders, who sell their goods on shabby blankets or on the bare ground. Street kids follow them, expecting money or other benefits. In the midst of poverty, Brenda and Legba appear like being from another planet: The color of Brenda's hair and skin attracts attention. She is the only white woman on the market. Legba stands out because of his clothing, differing from that of his fellow countrymen. Although they leave a trace of money and glad recipients behind them, the feeling remains that they don't belong there, that they don't belong to each other and that Brenda's grand entrance in the Port au Prince market is inappropriate.

A scene in Ellen's bungalow points out another disparity. It shows Ellen in a long morning robe, while Legba is lying naked on her bed. Automatically, Cantet evokes all the stereotypes from the exoticismdebate around 1900: the prudish, covered North and the hot South, where humans are no more than body and sex. Like during imperial times, it seems as if the whites try to take possession of the 'natural' and 'wild', because in their own culture it's missing. Ellen tries this in her own way, photographing the naked sleeping Legba. Certainly, this can be interpreted as a gesture of love or a homage to his beauty. But again, it can be seen in succession to, for example, the south-sea pictures of Gauguin in the 19th century and this connection opens once more the historical code of identity and otherness in modern Europe.

After all this the visual perception endures, that the couples in the movie don't belong together. Neither do they have the same cultural origin, nor do they belong to the same stratum, have the same color of skin or a similar education. The addiction to similarities that pushes internet dating services and matchmaking agencies in the search for a partner who 'fits' isn't a topic in Vers le sud. The protagonists are not similar except in one perspective: they are driven by the same dreams and wishes. Brenda, Ellen and Sue don't experience human attention in their home countries, while Legba and his friend live below the poverty line and surrounded by political oppression. What they share is that they wish for themselves a better life, just for once. A better life means, to Ellen, love and appreciation and, to Legba, food, money and personal freedom. 
In this way, Cantet designes the fiction of an exchange of resources, which culminates in hedonistic scenes on the beach of "Petite Anse", where all couples are unified in a happy atmosphere. There, not only the North American women can relax away from the cold and loneliness in their home countries but also Legba and his friends find peace and a little luxury, which they miss in their lives outside the hotel. Only the incident with young Eddy and Brenda reminds one, representatively for the whole picture, that the shown happiness is skating on thin ice.

\section{Dicourse on Cultural Values}

After the release of the movie, the reactions within critical circles weren't surprising: The waves rolled high and low. Many reviewers considered it as their duty to defend an assumed or existing canon of values and judged the actions of the female protagonists harshly.

Barbara Schweizerhof calls it "embarrassing" ("peinlich") that women at the age of fifty engage in a competition for whom is getting a privileged relation to an eighteen-year-old boy. Mick LaSalle describes Brenda, Ellen and Sue as "sexually invisible and in effect cast off by their world [...] Vulnerable in their lack of allure, they have found a country where the men are even more hopeless and powerless than they are." Considering the political and economic context, LaSalle accuses the female protagonists of being "corruptive" forces and blames Ellen for behaving grotesquely and exploitatively: "She [Ellen] can't face what she's doing is grotesque and exploitative [...]." He offers the view that North American money seduces young Haitians into prostitution and leads to the sellout of Haitian civilization. Indeed, the movie presents a society that suffers from destroyed social bonds: Legba doesn't visit his mother anymore and broke contact with his former girl-friend. It's open to question if this is a consequence of Legba's decision to be a consort of the North American tourists or a development which could be traced earlier.

In internet discussions and research literature Vers le sud is often interpreted in the context of imperialism. An IMDb user's review talks of "just another form of imperialism" and, in their work on postcolonial studies and intercultural cinema, Heffelfinger \& Wright come to the conclusion that "Legba's dependence on and resistance to Brenda allows Cantet to allude to the specter of American imperialism“ (120). This perspective is understandable with respect to Haitian history. Haiti once was one of the richest colonies in the 18th-century French empire, but only could be so through the work of African slaves who lived under the roughest conditions. In today's debate on imperialism, tourists are considered as the new exploiters: interpreters categorize female tourists and male locals into offenders and victims and talk of misuse of power, misusing political and economic weakness: “comment l' Occident capitaliste exploite le Tiers Monde sous-développé, à travers l'exemple du tourisme sexuel" (Berger in de Raedt 126). The debate shows that the disgust of the critics is produced by the normative demands of western societies. It remains questionable, though, if Cantet wanted to stage this, since the film itself isn't moralizing, but shows that such clear-cut categorizations like "this is sex tourism", "this is prostitution", "this is imperialistic exploitation" don't do justice to the staged phenomena.

\section{Reflection on Stereotypes}

In fact, Cantet plays with stereotypes. At the same time the movie alludes to them and undermines them in the course of the action, which mainly concentrates "on the personal lives of the women and the problematic exchange system they have entered into“ (Heffelfinger/ Wright 17). In his book Film und Stereotyp Schweinitz refers to similar techniques and points out that recent movies show the tendency to "use the world of stereotypes, 
but going beyond simple reproduction, they end up with a partial sovereignty towards the patterns. This often leads to their use as a symbolic form and on a second level to their application in a creative way [Weit häufiger als der Versuch demonstrativer Differenz ist heute allerdings das Bestreben, die Stereotypwelt anzuwenden, dabei aber über die einfache Reproduktion hinaus eine partielle Souveränität gegenüber den Mustern zu erlangen. Das läuft vielfach darauf hinaus, die patterns gleichsam als symbolische Formen zu benutzen und auf einer zweiten Ebene mit ihnen kreativ umzugehen]" (Schweinitz XIII). In Vers le sud Cantet experiments with stereotypes as categorizations that divide humans into groups: into men who engage with elderly women and are identified immediately as prostitutes, and women who are considered sex tourists, although this perspective is put into question in the course of the action. Thus, the discourse of the movie emphasizes the internalization of stereotypes in society. Just one symbol that belongs to a special category, like for example the money that Ellen puts into Legba's pocket, is needed to activate the stereotype in reception: i.e., prostitution. As a matter of fact, Cantet tries to break the stereotypes by highlighting qualities that contradict them, e.g. by paying attention to individual characteristics of the protagonists who are otherwise identified as group members, and by melting the boundaries between distinct social groups. As a result he pioneers new definitions. This impetus is visible in a lot of scenes, for example with regard to questions as to what makes a relation friendship and what makes it prostitution.

Ellen proclaims in the movie that she always told herself that she would pay young men to love her when she became old. Of course, this may refer to prostitution, but it's not possible to decide that on the basis of just one sentence. In all of the staged relations prostitution isn't a topic to talk about, a fact that might be a part of the deal. Furthermore, male prostitution isn't formalized, like female prostitution in other countries, and therefore a direct payment can't be traced. As nearly all of the women prefer to 'donate' food and material things to their 'boyfriends', the border between 'friendship with advantages' and prostitution often isn't visible. As Brenda, Ellen and Sue purchase a local as an escort for the duration of their stay it's possible, but not necessary to claim that they are involved in the "informal sex sector". It is important to add that the difficulty of judging in this case is a consequence of internalized stereotypes. Due to the fact that the relation between the North American women and the Haitian young men doesn't meet the pattern of a 'normal' relation in the eyes of the public, the gifts of the ladies are immediately identified as payment and the care of the men as sexual service. From this follows the categorization of the two groups into 'sex tourists' and 'prostitutes', although the movie provides enough hints that another denomination would be possible. None of the women seem to have changed their partners at any time. Sue visits Neptune, Ellen comes since six years ago to see Legba, while both Ellen and Brenda have offered to get Legba a passport, because they would like to take him to their homes. Sue affirms that she loves Neptune, while Ellen reportedly isn't sure about her feelings: "I'm crazy about love, sex and love. I'm not really sure anymore", she mentions in a conversation with Sue and Brenda. When Legba dies, the spectator sees a completely destroyed Ellen, who seems to have lost everything that meant anything to her. De facto, the tourists in the movie are not only interested in sex; they are looking for a partner. Concerning the young men, it also isn't that clear if they act according to pure material interests. In the moment when Legba sees Brenda for the first time after three years of absence, he is smiling at her: it seems to be a real pleasure for him to meet her again. The relations staged in the movie could thus relate to a common model of partnership: endearment in exchange for alimentation. In their home countries and with inverted gender roles, nobody would talk of prostitution. So, is it all about a gender trap? Are Legba and his friends automatically labelled as prostitutes as it is 'displeasing' that they engage with rich tourists, and can't the spectator believe Brenda, Ellen and Sue, that they are aiming at a loving relationship, because Legba and his friends aren't equivalent partners from a western point of view?

The question as to wheather the North American tourists are imperialistic exploiters or not is treated very similarly. Cantet provides important visual material that supports this perspective, but he complicates the view at 
the same time by focusing on individual fates that shift the viewpoint. In Cantet's film, as in recent research on tourism, "the focus has moved away from notions of invasion and exploitation towards trying to understand the process as interactive and contingent“ (Wearing, Stevenson \& Young 53). Thus, Legba and his friends are shown rather incidentally as 'victims' of the tourists; in fact, the film suggests that they had a choice, not only concerning different female favourers. The scene which shows Legba in conversation with the two young waitresses in front of the gazebo displays exactly this. Humorously, the girls propose a job exchange to Legba: he should lay the tables and they will go to fuck. Legba doesn't agree. Actually, the young Haitian males show a vivid interest in white women, and the exchange between the different individuals is staged rather as an interpersonal get-together with advantages on both sides than as exploitation.

On the other hand, Cantet expresses the essential role of money quite clearly in a deviation from the book that inspired him to make his movie. The original, Dany Laferrière's La chair du maitre (1997), is a collection of novellas with the common theme of sex, money and power during the Duvalier dictatorship. It deals with the relationships between white women and black men, including the tourists Ellen, Brenda and Sue "whose annual visits to the Hotel Anacaona formed the basis" of the movie (Pettinger 3). Complementary to the voices of the three women appears that of Albert, who delivers an accusation against the new white invaders: "They bring in their luggage a weapon much more destructive than guns: drugs. And the queen of crime is always accompanied by her two attendants: sex and easy money. There is nothing here, sir, that has not been touched by one or other of these three weapons" (Laferrière in Pettinger 4). The fundamental difference in Albert's account in the movie is that "drugs" and "sex" have disappeared and money is presented as the generalized evil: Albert talks of the new invaders who are not armed. They would bring in their luggage a weapon much more destructive than guns: "les dollars". Albert's point of view is supported by the film story. Money is at least part of the motivation for Legba and his friends to come into contact with Brenda, Ellen and Sue. Brenda reports in her monologue that she and her husband picked Legba from the street and that she had never seen someone eat so much. Most likely, Brenda and her husband saved Legba from starvation, from loneliness on the street and from a situation in which he had no attachment figure. Brenda and her husband arranged for Legba not only coverage of basic food requirements, they offered him emotional support, too. As Brenda said, they nearly "adopted" him. Legba probably felt obliged towards Brenda and her husband. Moreover, it can be accepted as a fact that he was attracted to the North Americans. They let him take part in a world that was usually not accessible to him. So, when he is touched by Brenda, he keeps silent. This money- and power-related seduction is paralleled by the story of Legba's girl-friend. She tells Legba how Colonel Beauvais made her become his concubine, gifting her flowers and jewelry.

\section{Alienation and Loneliness}

Complementary to the perspective of misused power structures between North and South (e.g. Brenda and Legba), political leaders and common folk (e.g. Colonel Beauvais and Legba's girlfriend) and a corresponding offender-victim relation, Cantet stages another aspect, that localizes the driving force not in money, but in a more general alienation and loneliness, both in Haitian and North American cultures.

Brenda and her husband met Legba as a loner, who seemingly wasn't integrated in social structures that could have held him. Although a mother existed, as the spectator learns from one of the last sequences in the film, Legba lived almost on the street. Also Legba's girl-friend complains in the carscene about her inner loneliness. She never had a real friend.

Likewise, alienation seems to rule the emotions of the North American tourists. The monologues of Brenda, Ellen and Sue, that provide an additional depth by focusing on individual perspectives, emphasize exactly 
this. Not until they are on holiday, can the female tourists live in harmony with their personalities; not until they are in Haiti are they able to satisfy their desires.

Ellen, who teaches French Literature at Wellesley, feels as if "Petite Anse" is her home; arriving in her bungalow means to her being "enfin chez moi". From her monologue the spectator learns that she doesn't find favour with the "snobs" in Boston. Also, she remarks the mating habits of her young female students with ironic distance and a sentiment of weariness towards the always identical incidents: the young goslings would spread their legs to get married, but then always come to school with tears in their eyes. Ellen guesses that the young men derive extreme arousal from their girl's tears. Her bitterness has its reasons, of course; the disappointments of her life are literally written in her face and are also manifested in her negative attitude towards men. Furthermore, it's Ellen's opinion that for women of a certain age, there are very few relationship options in and around Boston. She has visited every bar, but never found someone similar to Legba. In this respect, her monologue points out different phenomena: due to her age, but also to her emancipation, she doesn't fit into an ordinary life any more. She's not willing to accept her fate as an old maid, marginalized by society. She is longing for a relationship with a young attractive guy, and as her hometown can't offer her what she is looking for, she is willing to find her fortune somewhere else. Legba then appears to be the one who satisfies Ellen's dreams and wishes; she admires his beauty and could spend hours looking at him.

Brenda's alienation seems to have other reasons. In contrast to Ellen she was married and integrated in society, but she appears to have become stunted in this life. In her monologue she reports that she had her first orgasm with Legba at the age of forty-two. After the separation from her husband she came to Haiti to reclaim the passionate connection with Legba. In this context, again, it's up to the audience to guess what might be the reasons and motivations for Brenda to quit her old life and establish something new. Apparently Brenda hadn't managed to come into contact with her own sexuality and her own body within her marriage. It's not necessarily a matter of the prudish sex morals in the United States. It may also be Brenda's unconscious disgust towards traditional power relations. It's striking that Brenda experiences her first orgasm with a child or adolescent and that in this situation, the common power relation is inverted. After her liberation experience through violent sex she takes valium for a long time. To Legba she confesses that being separated from him meant physical pain to her. This pain might have been caused by the renewed loss of satisfying sexuality. One can surmise that Brenda's longing for Haiti is connected with a power problem from her self-analysis after Legba's death: she admits to Sue that she always hated the way her husband, her family and her friends looked at her because she felt judged by those looks. Legba, in contrast (and the audience knows: the child Legba), would have looked at her with other eyes: "[...] maybe I didn't love Legba. [...] But I loved the way he looked at me. I certainly loved that.“

Sue's alienation in comparison with Brenda's and Ellen's isn't very pronounced, but she, too, profits from the change of culture and space during vacation. Not until she is in Haiti does she feel like a butterfly, lively, free and unattached. In Canada her colleagues at work are almost all men, but she doesn't have a partner and has sex just infrequently. In her monologue she explains that she spent a beautiful night with a workmate in Canada, but he wouldn't have said a word the next day and she saw that he felt embarrassed about their being together. She couldn't make out what made him feel this way, but guesses that he maybe feared that she would like to marry him. Evidently this wasn't Sue's interest. Cantet shows her as a more 'natural' being who knows about her needs but fails due to the social mentality that doesn't offer companionship with occasional sex as a common model of partnership. On the other hand, Sue suffers from a widespread holiday-schizophrenia. She is deeply convinced that in Haiti "everything is different" and that even tourists aren't the same persons they were before. For some reason she considers Canada and Haiti as two completely discrete worlds, and this might explain why life in Haiti turns 
out very refreshing for her. She knows that she's just a guest, that she can decide whether and how long she stays and as a consequence her relationship to Neptune seems to be very "uncomplicated" to her.

Accordingly, Cantet depicts in Vers le sud how home-made social problems of the United States and Canada spill over the borders, get mixed up with postcolonial damage and enact new hierarchies. Vers le sud thus stages social change in present history: inverted gender roles, challenged cultural values, together with sex morals and concepts of partnership. Doing this, Cantet aims at a re-organization of cultural values by a fruitful play with stereotypes. To what degree this picture is realistic or representative of the social phenomenon remains to be seen.

\section{References}

Cantet, L., dir. (2005). Vers le sud. Franco-Canadian production. Paris: Haut et court, 115 min.

De Raedt, Th. (2008). Vers le Sud: De la violence, du pouvoir, du sexe et de l'argent. In J.Day (Ed.), Violence in French and Francophone Literature and Film (pp. 123-141). Amsterdam: Rodopi.

Dessalines, J.-J. (1804). Liberty or Death. Proclamation. Jean-Jacques Dessalines, Governor General, to the People of Hayti. The Balance, and columbian repository 25 (June 19, 1804), 197.

Frohlick, S. (2010). The Sex of Tourism? Bodies under Suspicion in Paradise. In J. Scott \& T. Selwyn (Eds.), Thinking Through Tourism (pp. 51-70). Oxford, UK: Berg.

Heffelfinger, E., \& Wright, L. (2011). Visual Difference: Postcolonial Studies and Intercultural Cinema. New York: Peter Lang.

Laguerre, M. S. (1998). The Voodooization of Politics in Haiti. In N. E. Whitten Jr. \& A. Torres (Eds.), Blackness in Latin America and the Caribbean: Social Dynamics and Cultural Transformations. (Vol. II: Eastern South America and the Caribbean, pp. 495-551). Bloomington: Indiana University Press.

LaSalle, M. (2006). On the Prowl in Haiti, Blind to Consequences. San Francisco Chronicle, Friday, September 1, 2006, E-5.

Lionnet, F. (2008). Postcolonialism, Language, and the Visual: By Way of Haiti. Journal of Postcolonial Writing 44): 227-239.

Pettinger, A. (2010). These New Plantations by the Sea': The Caribbean Hotel as Site of Exploitation and Scene of Writing. Paper presented at the University of Liverpool, 25 June 2010. http://www.liv.ac.uk/csis/blackatlantic/research/PlantationsByTheSea\%5B2\%5D.pdf

Rotberg, R. I. (1988). Haiti's Past Mortgages Its Future. Foreign Affairs 67, No. 1 (Fall, 1988): 93-109.

Rotberg, R. I. (1997). Haiti Renewed: Political and Economic Prospects. Washington D.C.: Brookings Institution Press.

Schweinitz, J. (2006). Film und Stereotyp. Eine Herausforderung für das Kino und die Filmtheorie. Zur Geschichte eines Mediendiskurses. Berlin: Akademie Verlag.

Schweizerhof, B. (2006) In den Süden. Film 9.

Wearing, St., \& Stevenson, D., \& Young, T. (2010). Tourist Cultures: Identity, Place and the Traveller. London: Sage. 
Judith Michelmann (PHD) is a Research Assistant to Prof. Dr. Ulrike Landfester at the Department of German Language and Literature at the University of St. Gallen, Switzerland. She is a lecturer in History of Media Communications, Modern History of Thought and Culture, and German Literature at the Universities of St. Gallen, Konstanz and Zurich. She earned her PhD in German Literature at the University of Konstanz (Germany) in 2010 with her thesis on the later version of Clemens Brentano: Gockel, Hinkel und Gackeleia. 